\title{
TIMING OF LITHOSPHERIC MANTLE MODIFICATION BENEATH THE WYOMING CRATON
}

\author{
Richard Carlson ${ }^{1}$, Anthony Irving ${ }^{2}$, Daniel Schulze ${ }^{3}$ and Carter Hearn $\mathrm{Jr}^{4}$ \\ ${ }^{1}$ CIW-DTM, USA; ${ }^{2}$ University of Washington, USA; ${ }^{3}$ University of Toronto, Canada; ${ }^{4}$ US Geological Survey
}

\section{INTRODUCTION}

Mantle xenoliths provide an important glimpse of the characteristics of the continental lithospheric mantle. The picture is complicated by the fact that many xenoliths have experienced a number of events that have modified their chemical and mineralogical makeup. In some cases, these modifications have occurred by interaction with passing melts and fluids during residence in the mantle. Other chemical and mineralogical overprints within xenoliths (i.e. not confined to grain boundaries) have resulted from interaction with transporting magmas, both before and during ascent. Distinguishing which of the observed characteristics of a mantle xenolith reflect features that were present in the mantle versus those that were introduced as a part of the magmatism that brought the sample to the surface is not always straightforward. This step, however, is critical if the xenoliths are to be used to interpret the long-term chemical and thermal history of the continental lithospheric mantle.

We report here an attempt to deconvolve the events that occurred in the lithospheric mantle of the Precambrian western United States through: 1) examination of xenoliths from nearby regions that experienced distinct tectonic histories, 2) comparison of xenolith characteristics in kimberlites erupted well before and during the regional late-Cretaceous, early-Tertiary, Laramide orogeny to examine the extent to which this event overprinted mantle characteristics throughout this area, and 3) use of a number of radiometric systems that have variable susceptibility to the effects of metasomatism. To accomplish this task we have obtained new chemical and $\mathrm{Sr}, \mathrm{Nd}, \mathrm{Hf}$, Os and $\mathrm{Pb}$ isotopic data for whole rock and mineral separates from garnet and spinel harzburgites, lherzolites and websterites from the Homestead and Sloan kimberlites, and new $\mathrm{Hf}$ isotopic data for previously studied (Carlson et al., 1999) garnet peridotites from the Williams kimberlite.

\section{GEOLOGIC SETTING}

From north to south (Fig. 1), the xenolith localities to be compared here include the Eocene Highwood and
Eagle Buttes centers (Carlson and Irving, 1994) that erupted through the Great Falls Tectonic Zone (GFTZ), a NE-SW trending belt that was tectonically, but not magmatically, active in the Proterozoic (O'Neill and Lopez, 1985). The GFTZ separates two Archean crustal blocks, the Medicine Hat Block (north) and the Wyoming Province (south). The $48 \mathrm{Ma}$ Williams kimberlite is one of the Missouri Breaks diatremes that were erupted near the border of the GFTZ and Wyoming Province (Hearn, 1989). The circa $50 \mathrm{Ma}$ Homestead kimberlite erupted through the northern Wyoming Province lithosphere in an area that has experienced minimal post-Archean tectonism, at least up until Laramide deformation and magmatism. The 380 Ma Sloan kimberlite (Smith et al., 1979) erupted along the Colorado-Wyoming border well south of the Wyoming Province in the 1.7-1.8 Ga juvenile arc crust of the Central Plains Orogen (Dutch and Nielsen, 1990).

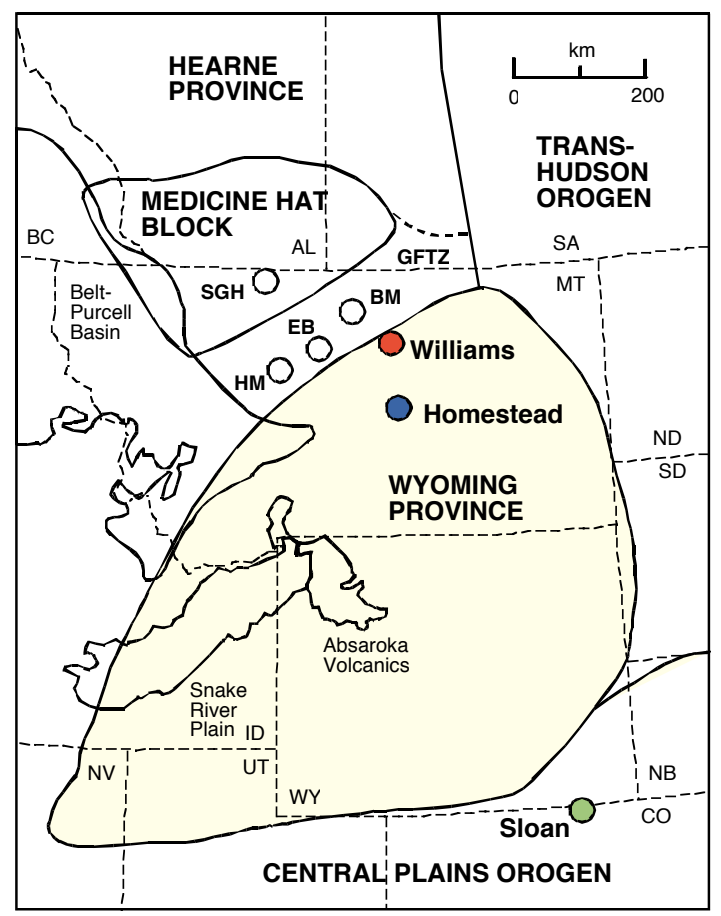

Figure 1: Tectonic setting of the Williams, Homestead and Sloan kimberlites (modified from Dutch and Nielsen, 1990). Other mantle and deep crustal xenolith localities are the Highwood Mountains (HM), Eagle Buttes (EB), Bearpaw Mountains (BM) and Sweet Grass Hills (SGH). 
Recent geophysical studies of this area (Gorman et al., 2002; Karlstrom et al., 2002) reveal deep crustal and upper mantle structures that aid in interpreting the assembly mechanism of this region. Recent results (Gorman et al., 2002) suggest that the Medicine Hat Block and the Wyoming Province are separate Archean terranes, with the GFTZ representing the suture zone. The timing of the suturing of the Wyoming-Medicine Hat blocks is uncertain. Gorman et al. (2002) suggest that assembly occurred in the late Archean through northward-dipping subduction. In contrast, the clear signature of pervasive circa $1.8 \mathrm{Ga}$ metasomatic overprinting of the shallow mantle sampled by the Eagle Buttes and Highwoods xenoliths (Carlson and Irving, 1994; Rudnick et al., 1999) suggests either midProterozoic reactivation of this boundary or that the assembly did not occur until the mid-Proterozoic. The importance of Proterozoic events is further highlighted by the presence of a 10-30 km thick high velocity lower crustal layer under the northern Wyoming ProvinceGFTZ interpreted to be underplated material (Gorman et al., 2002). The age of the underplating is indicated by a number of radiometric ages for lower crustal xenoliths from this area. A garnet granulite xenolith from the Sweet Grass Hills in northern Montana provides a Sm-Nd isochron age of $1696 \pm 6 \mathrm{Ma}$ with initial $\square \mathrm{Nd}=+0.3$ (Irving et al., 1997). Lower crustal xenoliths from the Sloan kimberlite give a wide range of $\mathrm{U}-\mathrm{Pb}$ zircon ages from Devonian through early Archean, but the dominant population falls in the age range 1640-1750 Ma (Karlstrom et al., 2002), similar to the Sweet Grass Hills result.

\section{XENOLITH SUITES}

The Williams kimberlite provides the northernmost xenolith sample set that extends well into the garnet stability field (Hearn and Boyd, 1975). Hearn and McGee (1984) showed that peridotite xenoliths from Williams define a slightly warm $\left(44 \mathrm{~mW} / \mathrm{m}^{2}\right)$ conductive geotherm with a marked step to much higher temperatures at relatively shallow depth $(<150$ $\mathrm{km})$. The Homestead kimberlite is a newly discovered xenolith locality in central Montana. The xenolith suite is dominated by harzburgites and dunites containing garnet, garnet plus spinel, or spinel. A few are low-Ca harzburgites with G10 garnets. Evidence of younger events shows in composite xenoliths that contain garnet, garnet-spinel, or spinel pyroxenite veins or selvedges, many of which also contain phlogopite. Phlogopite also occurs as disseminated grains, as rims on garnet, and in clinopyroxene-spinel clots. Peridotite xenoliths from Homestead sample to depths of at least
$120 \mathrm{~km}$ and are consistent with a much hotter Eocene geotherm of $60 \mathrm{~mW} / \mathrm{m}^{2}$ (Irving et al., 2003). The Sloan xenolith suite contains a variety of crustal and mantle xenoliths that have received considerable study (e.g. Smith et al., 1979; Eggler et al., 1987, 1988). Sloan peridotites define a $40 \mathrm{~mW} / \mathrm{m}^{2}$ conductive geotherm to depths of order $200 \mathrm{~km}$ (Eggler et al., 1987). The geotherm shown by Sloan xenoliths, however, provides a picture of mantle temperatures $380 \mathrm{Myr}$ ago. Present day surface heat flow (Decker et al., 1980) suggests that mantle temperatures beneath Sloan currently exceed $1500{ }^{\circ} \mathrm{C}$ at depths as shallow as $100 \mathrm{~km}$ (Eggler et al., 1988) indicating that the cool geotherm recorded by the xenoliths has been severely disturbed by Laramide tectonism and magmatism. Seismic imaging (Gorman et al., 2002; Karlstrom et al., 2002) shows that crustal and upper mantle structures dip to the north at the Cheyenne belt, the boundary between the Wyoming and Central Plains Orogen, suggesting northward convergence and underthrusting during Proterozoic assembly (Karlstrom et al., 2002). If so, only Proterozoic crust and upper mantle underlie Sloan. In contrast, studies of the mantle xenoliths from Sloan distinguish an upper depleted layer from a lower layer displaying the metasomatic enrichment in incompatible elements typical of Archean lithospheric mantle. This led Eggler et al. (1988) to conclude that the Wyoming Province underthrust the Central Plains Orogen. This conclusion, however, was reached on the basis of chemical comparisons with Archean cratonic peridotites and did not have the benefit of the radiometric chronology reported here.

\section{CHEMICAL CHARACTERISTICS}

Whole rock analyses show that the Homestead peridotites possess the magmaphile element depletion typical of cratonic lithospheric peridotites, as do the Williams peridotites (Carlson et al., 1999). For example, $\mathrm{Al}_{2} \mathrm{O}_{3}$ and $\mathrm{CaO}$ contents of the Homestead samples analyzed here range from 0.15 to 2.7 (mean $=$ $1.36, \mathrm{n}=8$ ) and 0.26 to 2.06 (mean $=1.05) \mathrm{wt} \%$, respectively. In contrast, the Sloan samples show a much wider range of fertility and are in general more fertile than samples from either Homestead or Williams. (Sloan $\mathrm{Al}_{2} \mathrm{O}_{3}=0.33$ to 3.96 , mean $=1.88$ $\mathrm{wt} \%, \mathrm{n}=7 ; \mathrm{CaO}=0.51$ to 3.34 , mean $=1.71 \mathrm{wt} \%$ ).

Perhaps the most striking contrast, however, is that both Homestead and Williams samples show strong incompatible element enrichment while the Sloan samples do not. This is seen most clearly by the primitive mantle normalized incompatible element patterns determined for acid-washed minerals separated 


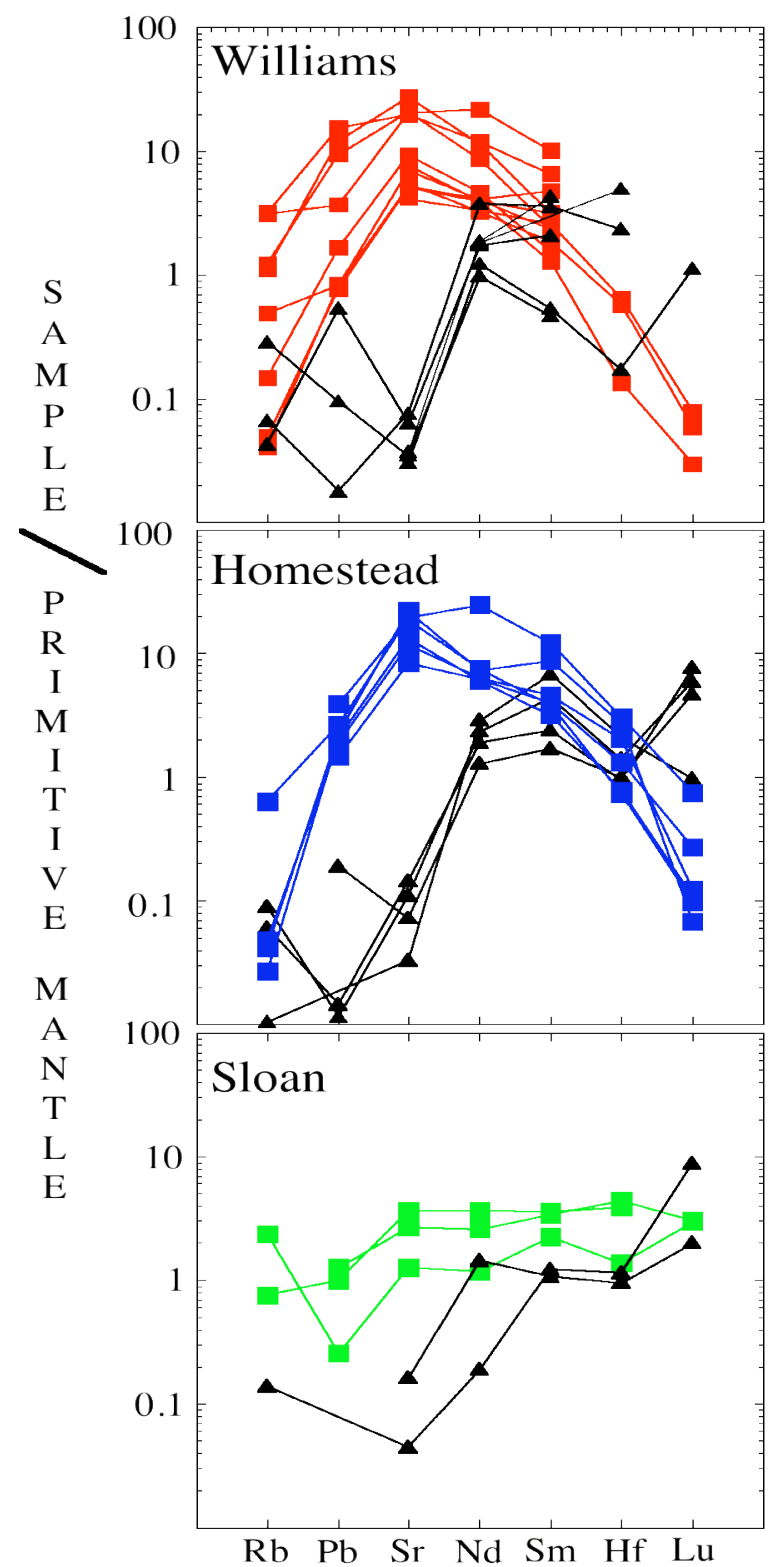

Figure 2: Primitive mantle (McDonough and Sun, 1995) normalized abundances of incompatible elements in clinopyroxene (squares) and garnets (triangles) separated from the samples studied here.

from these samples (Fig. 2). Both the Williams and Homestead pyroxenes show strongly U-shaped patterns with dramatic enrichments in LREE and Sr, while the Sloan pyroxenes show smooth patterns of decreasing abundance with increasing compatibility as would be expected for simple single-stage residues of melt extraction. In other words, the Sloan samples analyzed here do not show evidence for metasomatism whereas both the Williams and Homestead samples do. Eggler et al. (1988) report REE data for pyroxenes from Sloan xenoliths that are similar to those shown in figure 2, but also measured samples from deeper in the stratigraphic column that have the strong LREE enrichment typical of our Williams and Homestead samples.

\section{Ages of Chemical Modification}

Removal of partial melt is the most likely explanation for the magmaphile element depletion characteristic of most of the peridotites analyzed here. This event is perhaps best dated with the Re-Os system, though the Lu-Hf system also may be sufficiently insensitive to metasomatism or host kimberlite contamination to provide useful information on the timing of melt depletion (Schmidberger et al., 2001). The Homestead samples show a fairly narrow range in Re-depletion model ages $\left(\mathrm{T}_{\mathrm{RD}}\right)$ with 7 out of 8 samples between 2.24 and $2.69 \mathrm{Ga}($ mean $=2.49 \mathrm{Ga})$. The Os isotopic composition of these samples does not correlate with either $\mathrm{Al}_{2} \mathrm{O}_{3}$ or $\mathrm{Re} / \mathrm{Os}$, which shows that even the ReOs system has been significantly affected by metasomatism in the Homestead samples. The 4 samples with lowest $\mathrm{Re} / \mathrm{Os}$ ratios define Re-Os mantle model ages ranging from 2.81 to $3.42 \mathrm{Ga}$. Though these data do not provide precise ages for the melt depletion, the mean Re-depletion age of $2.49 \mathrm{Ga}$, which represents a minimum age for this event, indicates that the majority of Homestead peridotites were depleted by melt removal that most likely occurred in the Archean. This age range mirrors the data obtained previously for low-T peridotites from Williams (Re-depletion ages from 1.69 to $2.49 \mathrm{Ga}$, Carlson et al. (1999)).

Sloan xenoliths provide a wide range, but generally younger Re-depletion ages $(0.64$ to $2.39 \mathrm{Ga}$, mean = $1.36, \mathrm{n}=6$ ). These ages overlap the range reported for high- $\mathrm{T}$ peridotites from Williams $\left(\mathrm{T}_{\mathrm{RD}}=0.72\right.$ to 0.83Ga; Carlson et al., 1999). Unlike Homestead, the Sloan samples show a very rough correlation between Os isotopic composition and both $\mathrm{Al}_{2} \mathrm{O}_{3}$ and Re/Os. The Os isotope $-\mathrm{Al}_{2} \mathrm{O}_{3}$ correlation extrapolates to ${ }^{187} \mathrm{Os} /{ }^{188} \mathrm{Os}=0.116$ at $\mathrm{Al}_{2} \mathrm{O}_{3}=0$, corresponding to a $\mathrm{T}_{\mathrm{RD}}$ of $1.77 \mathrm{Ga}$. The Re-Os correlation, though definitely not a statistically valid isochron, corresponds to an age of $775 \pm 207 \mathrm{Ma}$. Circa 800-1200 Ma slopes also can be found in various combinations of mineral and whole rock data for Sloan samples in the Rb-Sr, $\mathrm{Sm}-\mathrm{Nd}$ and Lu-Hf systems (Fig. 3). Most noticeable is that clinopyroxene, whole rock, and garnet separates from one Sloan garnet lherzolite define a Sm-Nd "isochron" of $899 \pm 110 \mathrm{Ma}(\mathrm{MSWD}=17)$ with initial $\square \mathrm{Nd}$ of +10.7 . Whether or not these ages have any chronological significance is unclear, but they do support the idea that the Sloan samples have been 
relatively minimally affected by contamination from the host kimberlite. What is most distinctive about the isotopic results for the Sloan samples is that many have the high ${ }^{143} \mathrm{Nd} /{ }^{144} \mathrm{Nd}$ and ${ }^{176} \mathrm{Hf} /{ }^{177} \mathrm{Hf}$ expected for old residues of melt depletion. Sloan whole rocks have $\square \mathrm{Nd}$ between +1.8 and +10.5 with $\square$ Hf between -3.5 and +33.6 , with clinopyroxenes extending these values to $\square \mathrm{Nd}=+9.8$ to +35.3 and $\square \mathrm{Hf}=+1.7$ to +34.9 . The Sloan samples broadly define a slope in $\mathrm{Nd}-\mathrm{Hf}$ isotopic space similar to the mantle array shown by oceanic basaltic rocks, but extend to significantly higher values than any oceanic basalt. For the Sloan clinopyroxenes with $\mathrm{Sm} / \mathrm{Nd}$ and $\mathrm{Lu} / \mathrm{Hf}$ significantly higher than fertile mantle values, these isotopic compositions translate into depleted mantle model ages ranging from 1.35 to $1.71 \mathrm{Ga}$.

In contrast to Sloan, xenoliths from both Homestead and Williams show complicated isotope systematics indicative of interaction with metasomatic fluids/melts, most likely associated with the host kimberlites or their precursors. This is shown most clearly in the middle panel of figure 3 where it can be seen that the Sm-Nd data for both the Williams and Homestead whole rocks and clinopyroxenes cluster close to the Sm-Nd characteristics of the host kimberlites (Homestead kimberlite ${ }^{143} \mathrm{Nd} /{ }^{144} \mathrm{Nd}=0.51232$ ) with garnet data trending off on shallow slopes approaching those expected for host kimberlite ages. The Homestead samples show a similar story in their Rb-Sr systematics, but the Williams clinopyroxenes show a wide range in ${ }^{87} \mathrm{Sr} /{ }^{86} \mathrm{Sr}$ that is not accompanied by significant variation in $\mathrm{Rb} / \mathrm{Sr}$. Both Williams and Homestead clinopyroxenes show a wide range in $\mathrm{Hf}$ isotopic compositions that are not supported by corresponding variation in Lu/Hf. Initial Hf isotopic compositions of the Homestead clinopyroxenes range from near the value for the host kimberlite $\left({ }^{176} \mathrm{Hf} /{ }^{177} \mathrm{Hf}=0.28246\right)$ to large positive values that would be expected for old LIL-depleted residual mantle. Assuming, just for example, that the Homestead mantle was depleted at 2.7 $\mathrm{Ga}$, in order to reach the highest ${ }^{176} \mathrm{Hf} /{ }^{177} \mathrm{Hf}$ measured for a Homestead clinopyroxene $(\square \mathrm{Hf}=+45)$ would require a ${ }^{176} \mathrm{Lu} /{ }^{177} \mathrm{Hf}=0.058$, which is similar to the $\mathrm{Lu} / \mathrm{Hf}$ measured for the depleted Sloan whole rocks. The Lu-Hf system in some peridotites from both Homestead and Williams peridotites thus carries evidence of the depletion event recorded by the major element composition and Re-Os isotopic system of these samples. Other Homestead samples have completely exchanged their Hf with the host kimberlite. The fact that the $\mathrm{Nd}$ isotopic compositions of all Homestead and Williams clinopyroxenes are below
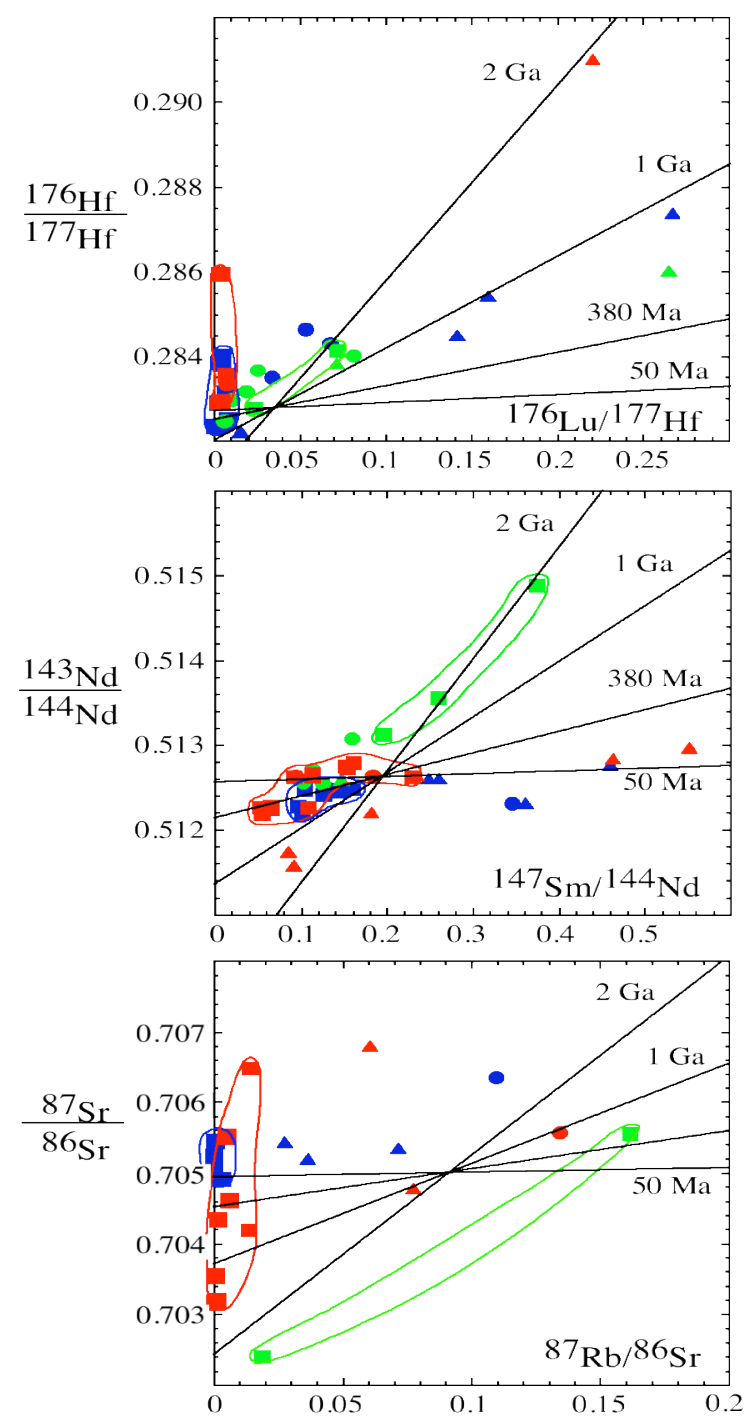

Figure 3. Isotopic compositions for Sloan (green), Homestead (blue) and Williams (red) samples. Circles show data for whole rocks, triangles garnets, and squares clinopyroxene (also enclosed by colored fields). The lines show the slopes, starting from primitive mantle, for ages equal to kimberlite eruption (50 and $380 \mathrm{Ma}$ ) and 1 and $2 \mathrm{Ga}$.

chondritic and approach the values measured for the host kimberlites is an indication that this exchange and/or overprinting is much more efficient for $\mathrm{Sr}$ and $\mathrm{Nd}$ than Hf. That this is a diffusion controlled process is suggested by the fact that acid-washed garnet-cpx tie lines for Homestead peridotites provide slopes on a LuHf isochron diagram corresponding to ages between 250 and $780 \mathrm{Myr}$, whereas these same samples on a $\mathrm{Sm}-\mathrm{Nd}$ isochron diagram provide ages of 60-215 Ma, most of which overlap within uncertainty the age of the host kimberlite. Unlike Albarede et al. (2002) and Bedini et al. (2002), we interpret these disparate mineral ages not as closure ages for a slowly cooling 
lithosphere, but as artifacts of the more rapid reequilibration of the $\mathrm{Sm}-\mathrm{Nd}$ compared with the $\mathrm{Lu}-\mathrm{Hf}$ system. The result of this process is that the Homestead and Williams samples describe a nearly vertical trend in $\mathrm{Nd}-\mathrm{Hf}$ isotopic space extending from within the mantle array to well above the array. We suspect that this is not a general characteristic of the subcontinental mantle, but rather an artifact of recent interaction between xenolith and alkalic magmas. We point out that few magmas other than carbonatites have isotopic compositions plotting well above the Nd-Hf mantle array. Eocene carbonatites are common around the Homestead area and possibly could have been an important metasomatic fluid in the mantle beneath this area.

\section{REFERENCES}

Albarede, F., Bedini, R.-M., Blichert-Toft, J., Boyet, M., 2002. Sm-Nd and Lu-Hf ages of ultramafic xenoliths from South African kimberlites and the secular cooling of the Earth. EOS Trans. Am. Geophys. Union, 83: Abstract MR71B-05.

Bedini, R.M., Blichert-Toft, J., Boyet, M., Albarède, F., 2002. Lu-Hf isotope geochemistry of garnet-peridotite xenoliths from the Kaapvaal craton and the thermal regime of the lithosphere. Abstract. Geochim. Cosmochim. Acta, Special Supplement 66(15A): A61.

Carlson, R.W. and Irving, A.J., 1994, Depletion and enrichment history of subcontinental lithospheric mantle: $\mathrm{Os}, \mathrm{Sr}, \mathrm{Nd}$ and $\mathrm{Pb}$ evidence for xenoliths from the Wyoming craton. Earth Planet. Sci. Lett. 126, 457-472.

Carlson, R.W., Irving, A.J., and Hearn, B.C. Jr., 1999, Chemical and isotopic systematics of peridotite xenoliths from the Williams kimberlite, Montana: Clues to processes of lithosphere formation, modification and destruction, in Gurney, J.J., Gurney, J.L., Pascoe, M.D., and Richardson, S.H., eds., Proc. 7th Int. Kimberlite Conf., Cape Town, Red Roof Design, p. 90-98.

Decker, E.R., Baker, K.R., Bucher, G.J., and Heasler, H.P., 1980, Preliminary heat flow and radioactivity studies in Wyoming, J. Geophys. Res. 85, 311-321.

Dutch, S. I., and P. A. Nielsen, 1990, The Archean Wyoming Province and its relations with adjacent Proterozoic provinces, in The Early Proterozoic Trans-Hudson Orogen of North America, Lewry, J.F. and Stauffer, M.R. eds., Geol. Assoc. Canada Spec. Paper, 37, 287300.

Eggler, D.H., McCallum, M.E., and Kirkley, M.B., 1987, Kimberlite-transported nodules from ColoradoWyoming; A record of enrichment of shallow portions of an infertile lithosphere, in Morris, E.M. and Pasteris, J.D., eds., Mantle metasomatism and alkaline magmatism, Geol. Soc. Am. Spec. Paper 215, 77-90.

Eggler, D.H., Meen J.K., Welt, F., Dudas, F.O., Furlong, K.P., McCallum, M.E., and Carlson, R.W., 1988, Tectonomagmatism of the Wyoming Province, in
Colorado Volcanism, J. Drexler and E. E. Larson ed., Colorado School of Mines Quarterly 83, 25-40.

Gorman, A.R., Clowes, R.M., Ellis, R.M., Henstock, T.J., et al., 2002, Deep Probe: imaging the roots of western North America, Can. J. Earth Sci. 39, 375-398

Irving, A.J., Kuehner, S.M., and Carlson, R.W., 1997, 1.70 $\mathrm{Ga} \mathrm{Sm}-\mathrm{Nd}$ age for a garnet granulite xenolith from a minette sill, Sweet Grass Hills, Northern Montana supports Proterozoic collision of Hearne and Wyoming cratons, EOS, Trans. Am. Geophys. Union 78, 786.

Hearn, B. C., Jr., 1989, Alkalic ultramafic magmas in northcentral Montana, USA: Genetic connections of alnoite, kimberlite, and carbonatite, in Jaques, A. L., Ferguson, J., and Green, D. H., eds., Kimberlites and Related Rocks - Volume 1, Geol. Soc. Australia Spec. Publ. 14: Oxford, Blackwell, p. 109-119.

Hearn, B. C. Jr., and Boyd, F. R., 1975, Garnet peridotite xenoliths in a Montana, U.S.A., kimberlite: Phys. Chem. Earth, v. 9, p. 247-256.

Hearn, B. C. Jr., and McGee, E. S., 1984, Garnet peridotites from Williams kimberlites, north-central Montana, USA, in Kornprobst, J., ed., Kimberlites II: The Mantle and Crust-Mantle Relationships: Amsterdam, Elsevier, p. 5770.

Irving, A.J., Kuehner, S.M. and Ellsworth, P.C., 2003, Petrology and thermobarometry of mantle xenoliths from the Eocene Homestead kimberlite pipe, central Montana, USA, 8th Int. Kimb. Conf. Abstr.

Karlstrom, K.E., Bowring, S.A., Chamberlain, K.R., Dueker, K.G., et al., 2002, Structure and evolution of the lithosphere beneath the Rocky Mountains: Initial results from the CD-ROM experiment, GSAToday 12, 4-10.

McDonough, W.F. and Sun S.-s., 1995, Composition of the Earth, Chem. Geol. 120, 223-253.

O'Neill, J.M. and Lopez, D.A., 1985, Character and regional significance of Great Falls tectonic zone, east-central Idaho and west-central Montana, Am. Assoc. Petrol. Geol. Bull. 69, 437-447.

Rudnick, R. L., T. R. Ireland, G. Gehrels, A. J. Irving, J. T. Chesley, and J. M. Hanchar, 1999, Dating mantle metasomatism: $\mathrm{U}-\mathrm{Pb}$ geochronology of zircons in cratonic mantle xenoliths from Montana and Tanzania, in in Gurney, J.J., Gurney, J.L., Pascoe, M.D., and Richardson, S.H., eds., Proc. 7th Int. Kimberlite Conf., Cape Town, Red Roof Design, 728-735.

Schmidberger, S.S., Simonetti A., Francis, D. and Gariepy, C., 2002, Probing Archean lithosphere using the Lu-Hf isotope systematics of peridotite xenoliths from Somerset Island kimberlites, Canada, Earth Planet. Sci. Lett. 197, 245-259.

Smith, C.B., McCallum, M.E., Coopersmith, H.G., and Eggler, D.H., 1979, Petrochemistry and structure of kimberlites in the Front Range and Laramie Range, Colorado-Wyoming, in Boyd, F.R. and Meyer, H.O.A., eds, Kimberlites, diatremes, and diamonds; Their geology, petrology, and geochemistry, American Geophysical Union, Washington DC, 178-189.

Contact: R.W. Carlson, Carnegie Institution of Washington, Department of Terrestrial Magnetism, 5241 Broad Branch Road, NW, Washington, DC, 20015, USA, E-mail: carlson@dtm.ciw.edu 